\title{
Temporal distribution of ten calyptrate dipteran species of medicolegal importance in Rio de Janeiro, Brazil
}

\author{
Rodrigo Rocha Barbosa $/{ }^{+}$, Cátia Antunes de Mello-Patiu, Alexandre Ururahy-Rodrigues, \\ Celso Guimarães Barbosa, Margareth Maria de Carvalho Queiroz
}

Laboratório de Transmissores de Leishmaniose, Instituto Oswaldo Cruz-Fiocruz, Av. Brasil 4365, 21045-900 Rio de Janeiro, RJ, Brasil

Brazilian studies involving entomological succession patterns in carcasses have been used to describe the necrophagous entomofauna of a determined municipality or region with forensic objectives. Following the same objectives, an ecological study with 10 calyptrate dipterans was carried out during the winter of 2007 and the summer of 2008 in the metropolitan region of the municipality of Rio de Janeiro. The aim of this study was to describe several aspects of the phenology of these species in three neighbouring areas. Carcasses of three domestic pigs (Sus scrofa L.) were used in each season as models for forensic and legal medicine investigations in the region. Temperature, relative humidity and rainfall were measured daily and their relations with population abundance of the colonising species and the decomposition stages were analysed. Ten fly species were recorded to be colonising the carcasses, five of which belonged to the Calliphoridae family, three to the Muscidae, one to the Fanniidae and one to the Sarcophagidae family. Data show preferences of these species for climatic season and decomposition stage, as well as for the studied area and suggest that short distances can significantly influence the abundance of some species.

Key words: calyptrate dipterans - domestic pigs - decomposition - Brazil - forensic entomology

Knowledge of the necrophagous entomofauna is one of the bases of forensic entomology. In fact, it contributes to the understanding of the temporal distribution and behaviour of many species that are also active in the decomposition of human corpses (Smith 1986, Catts \& Haskell 1991, Byrd \& Castner 2001). A large number of worldwide studies have been carried out to identify the insects that are associated with the degradation of corpses; these studies have mainly aimed to observe the ecology of the species involved (Benecke 2001). The results of these studies are used as a tool for bioecological, morphological and molecular studies of potential importance for forensic entomology. Through these studies, entomological methods may also be applied as an auxiliary tool for criminal investigations (Oliveira-Costa 2007).

Calyptrate flies [e.g., the blowflies (Calliphoridae) and the domestic flies (Muscidae)] have an extensive variety, different strategies of survival and very diverse bionomic characteristics, including hematophagy, viviparity and endoparasitism (McAlpine 1989, Yates \& Wiegmann 1999). Among them, four families are of great forensic importance throughout the world and also in the municipality of Rio de Janeiro: Calliphoridae, Sarcophagidae, Muscidae and Fanniidae (Salviano 1996, Barbosa et al. 2009).

Two main groups of necrophagous calyptrate dipterans can be collected in association with carcasses; the first looks for animal protein for ovarian development and the second uses it as temporary resource for larvae

Financial support: PAPES V/CNPq (403482/2008-9)

+ Corresponding author: rodrigorb1@hotmail.com

Received 16 October 2009

Accepted 3 February 2010 breeding. In the latter case, these insects normally have a preference for certain stages of carcass decomposition, thereby allowing the forensic entomologist to determine the postmortem interval (PMI) (Kamal 1958, Smith 1986, Greenberg 1991). Additionally, other important aspects in a criminal investigation can be considered, such as determining the cause of death, confirming the hypothesis of neglect of children or the elderly and investigating the possibility that a corpse was moved from the crime scene (Benecke 2001, Benecke \& Lessig 2001).

In Brazil, the number of studies involving necrophagous entomofauna has increased in recent years. However, considering the country dimensions and its megadiversity of species, there is a need for additional studies (Pujol-Luz et al. 2008).

The present paper aims to identify, quantify and analyse the ecological aspects of ten calyptrate dipterans with forensic entomological importance, in order to improve the possibility of estimating the minimal PMI and to evaluate the existence of population variations between three neighbouring areas in the Rio de Janeiro municipality.

\section{MATERIALS AND METHODS}

Study location - The study was carried out in the north side of Rio de Janeiro, a municipality in Southeast Brazil. Three neighbouring locations with different physiographic characteristics within the large area of the Fundação Oswaldo Cruz-Fiocruz were chosen for the experiments and were named area $1\left(22^{\circ} 52^{\prime} 33^{\prime \prime} \mathrm{S}\right.$ $\left.43^{\circ} 14^{\prime} 47^{\prime \prime} \mathrm{W}\right), \quad 2 \quad\left(22^{\circ} 52^{\prime} 21^{\prime \prime} \mathrm{S} \quad 43^{\circ} 14^{\prime} 49^{\prime \prime} \mathrm{W}\right)$ and 3 (22 $\left.2^{\circ} 52^{\prime} 27^{\prime \prime} \mathrm{S} 43^{\circ} 14^{\prime} 40^{\prime \prime} \mathrm{W}\right)$ (Supplementary data).

Area 1 was situated $20 \mathrm{~m}$ from a place with moderate movement of vehicles and people; its vegetation was mostly composed by Eugenia jambolana (jamelão) and Panicum maximum (capim-colonião) and the carcass 
was placed in a location that was partially protected from direct sunlight. Area 2 was located about $100 \mathrm{~m}$ from movement of vehicles and people; its hard vegetation was mainly composed by Caesalpina ferrea (pauferro) and the carcass was totally protected from the sun. Area 3 was positioned $10 \mathrm{~m}$ from a place with abundant movement of people and vehicles; its vegetation was composed by E. jambolana, Lecythis sp. (sapucaia) and P. maximum and the carcass was exposed to the sun for almost the entire day. The experiments were carried out during the winter of 2007 (from August 15 2007-August 27 2007) and the summer of 2008 (from January 16 2008-January 30 2008).

Experimental model - For each study season, three domestic pigs (Sus scrofa L.) weighing $15 \mathrm{~kg}$ were used, one for each area. They were obtained from a pig farm, killed on location by a blow to the skull at 10 am and immediately transported in sealed plastic bags to the study area, where they were set out one hour later.

Model of traps - The traps model and the field protocols were the same as those proposed by Salviano (1996). The adults were collected daily between 12-2 $\mathrm{pm}$, at which time the collector was replaced by a new one. In the laboratory, the collector tube was placed in a freezer at $-17^{\circ} \mathrm{C}$ for $40 \mathrm{~min}$. After freezing, the insects were transferred to test tubes that were labelled with the date, the hour, the carcass number and the locality. The material was returned to the freezer for posterior sorting, identification and counting of specimens. To confirm which species had colonised the carcasses, egg samples were collected and placed on filter paper and after eclosion, the first instar larvae were placed on decomposing flesh to obtain the adults. Larvae and pupae from the carcasses and the immediate surroundings were also collected for the same reason.

Abiotic variables register - The local temperature and the relative humidity of air $(\mathrm{RH})$ were measured daily at the collection time with a Thomas Scientific ${ }^{\circledR}$ thermal hygrometer.

Identification of specimens - The Calliphoridae were identified using the key proposed by Mello (2003). The Muscidae and Fanniidae were identified using the keys proposed by Carvalho and Couri (2002), Couri and Carvalho (2002) and Carvalho et al. (2002). The male Sarcophagidae were identified using the key proposed by Carvalho and Mello-Patiu (2008) and the females were identified by comparison with the Sarcophagidae collection of the Entomology Department of Museu Nacional, Universidade Federal do Rio de Janeiro.

The decomposition stages - To evaluate the decomposition, stages were classified using the terminology of Tullis and Goff (1987) and the morphological modifications of the carcass were adjusted to decomposition time in our climatic conditions and subdivided into days.

Statistical analyses - To evaluate the relative abundance of the species and their possible preference for the area studied (area 1, 2 or 3), carcass decomposition stages and seasons, the analysis of variance (ANOVA) (Sokal \& Rohlf 1995) of the three factors (area of study, stage of decomposition and season) was carried out and the relative abundance was the variable response. Significances were determined by the Tukey test $(p \leq$ 0.05 ). The species that were not found in their immature stages on the carcass during the decomposition process were excluded from the statistical analyses, due to their lesser importance as forensic indicators. The immature samples were qualitative and were not included in the statistical analyses.

\section{RESULTS}

Decomposition process - The following five decomposition stages were observed: fresh, bloated, decay, post-decay and skeletonisation. Differences in the duration of decomposition stages at each area and between the seasons studied were only observed in the summer. Each stage was divided into a number of days according to the morphological changes observed (Fig. 1).

Meteorological data - For both seasons, the ambient temperature and $\mathrm{RH}$ were recorded daily at the location of each carcass (Figs 2-5).

Species composition - The following 10 species were collected as adults and also as larvae colonising the carcasses: Chrysomya albiceps (Wiedemann 1819), Chrysomya megacephala (Fabricius 1794), Chrysomya putoria (Wiedemann 1818), Hemilucilia segmentaria (Fabricius 1805), Lucilia eximia (Wiedemann 1819), Ophyra aenescens (Wiedemann 1830), Ophyra chalcogaster (Wiedemann 1824), Synthesiomyia nudiseta (Wulp 1883), Fannia pusio (Wiedemann 1830) and Peckia (Pattonella) intermutans (Thomson 1869). Table I shows the absolute and relative abundance of each species in the two studied seasons.

Species vs. season - According to ANOVA and Tukey tests, five species showed significant differences in their abundances and averages. F. pusio was more abundant in the winter; in fact, $81.4 \%(\mathrm{p}<0.01)$ of the specimens were collected in this season. On the other hand, some species were more abundant in the summer, such as $O$. aenescens, with $88.1 \%(\mathrm{p}<0.01)$, C. megacephala, with $96.3 \%$ ( $\mathrm{p}<$ $0.01)$, C. putoria, with $93.6 \%(\mathrm{p}<0.01)$, and H. segmentaria, with $62.7 \%(\mathrm{p}<0.05)$.

In the winter, $F$. pusio had a significant relation to area 2 when compared with area 3 only, where $56.9 \%$ $(p<0.01)$ of the specimens were collected. The other studied species showed variations of their abundances, but there was no significant difference between the areas (Supplementary data).

When the average number of individuals from each species was compared in the summer, most of the significant differences occurred between areas 2-3. Note that $70.8 \%$ of the specimens of $O$. aenescens in this season were collected from area $2(\mathrm{p}<0.01) ;$ C. megacephala also had a preference for this area, with $55.6 \%$ of the specimens $(\mathrm{p}<0.05)$ and the same occurred with $C$. albiceps, which made up 48.1\% $(\mathrm{p}<0.05)$. However, area 2 had significant differences with the other areas when considered simultaneously: $O$. chalcogaster had $69.7 \%$ $(\mathrm{p}<0.01)$ and H. segmentaria had 57.5\% $(\mathrm{p}<0.01)$ (Supplementary data). 


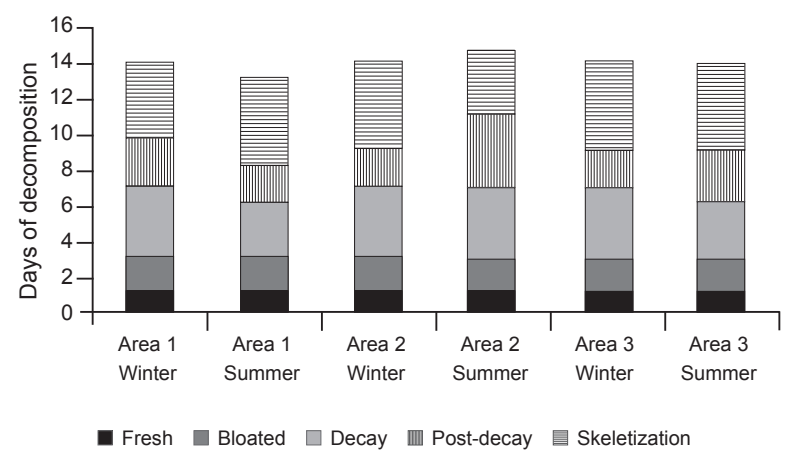

Fig. 1: duration of the carcass decomposition stages in each study area.

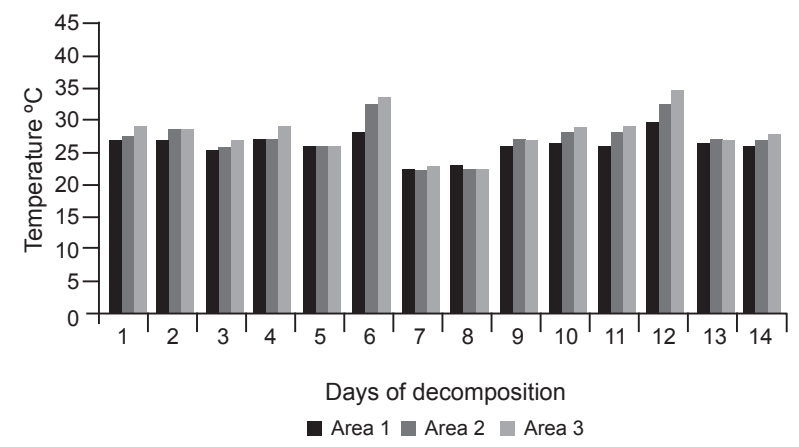

Fig. 2: ambient temperature $\left({ }^{\circ} \mathrm{C}\right)$ data for each study area in winter 2007.

Relation between coloniser species vs. decomposition stages - Table II shows the absolute and relative number of adults captured during the experiment, statistically correlated to the stages of carcass decomposition. C. megacephala showed a preference for the bloating and decay stages of summer and more than $80 \%$ occurred in these two stages alone. $H$. segmentaria had a significant preference for the bloating stage in both seasons; this species was considered to be one of the pioneers in the decomposition process.

O. aenescens was highly abundant in the decay stage of the summer, with 1,476 (66.3\%) specimens captured. There was no significant difference between the other decomposition stages for this species. However, S. nudiseta was captured in greater numbers in the winter of 2007 and had a significant preference for the bloating stage in the winter, the stage in which it was considered to be a pioneer in the decomposition process, with 523 (51\%) specimens captured. F. pusio was the most numerous insect in the whole experiment, but its appearance was only significant in the winter decay stage, when 1,305 (41.9\%) specimens were collected.

\section{DISCUSSION}

Forty-five calyptrate species were collected in the two experiments, although most of them probably went to the carcasses to feed and only 10 were found colonising the

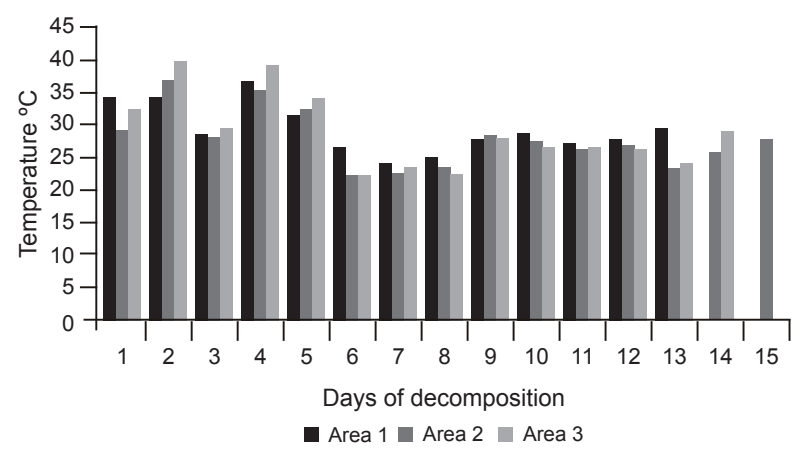

Fig. 3: ambient temperature $\left({ }^{\circ} \mathrm{C}\right)$ data for each study area in summer 2008.

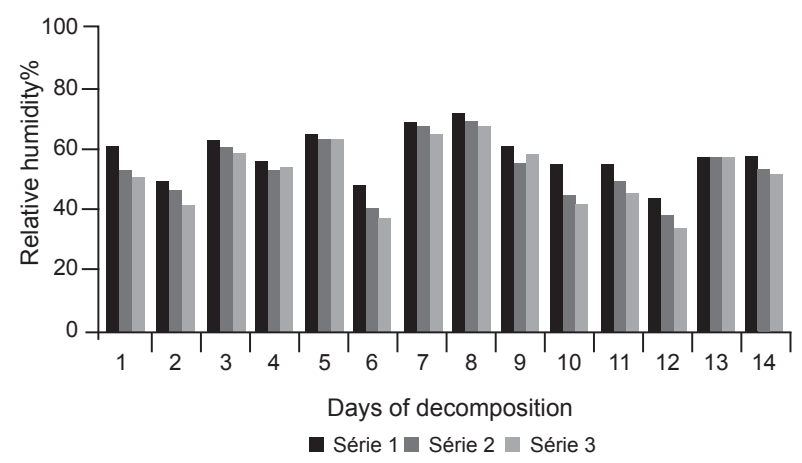

Fig. 4: relative humidity (\%) data for each study area in winter 2007.

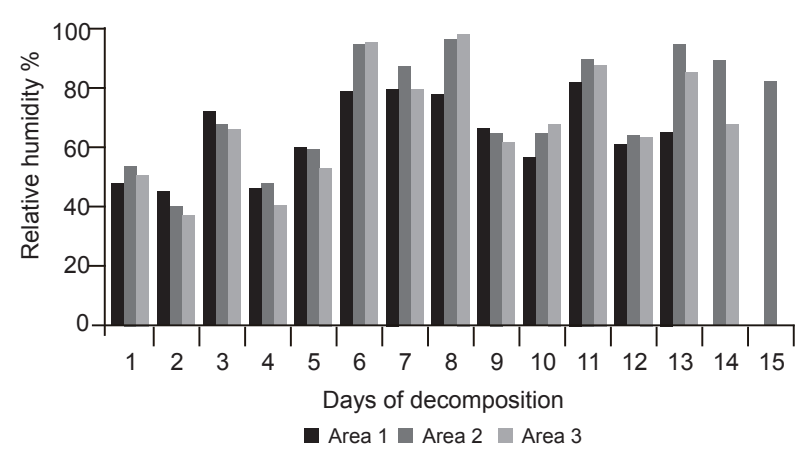

Fig. 5: relative humidity (\%) data for each study area in summer 2008.

models. These results are in accordance with Johnson (1975) and Carvalho et al. (2000), who pointed out that few species actually have value for forensic entomology. Only the species that use the corpses as the substrate for development of the immature forms are important for determination of the PMI interval through assessment of their post-embryonic development (Erzinçlioglu 1985, Greenberg 1991, Goff 2000).

Succession patterns of the calyptrate flies in these experiments were not clearly observed, a fact also reported by Salviano (1996) in the same studied area. Contrasting results have been observed in experiments 
TABLE I

Absolute and relative abundance of colonizing species in each studied season

\begin{tabular}{|c|c|c|c|c|}
\hline \multirow[b]{2}{*}{ Species } & & \multicolumn{2}{|c|}{ Season } & \multirow[b]{2}{*}{ Total } \\
\hline & & Winter & Summer & \\
\hline \multirow{3}{*}{ Chrysomya albiceps } & $\mathrm{n}$ & 362 & 636 & 998 \\
\hline & $\%$ & 36.3 & 63.7 & 100 \\
\hline & $\overline{\mathrm{X}}$ & $3.580^{a}$ & $4.686^{a}$ & - \\
\hline \multirow{3}{*}{ Chrysomya megacephala } & $\mathrm{n}$ & 62 & 1,617 & 1,679 \\
\hline & $\%$ & 3.7 & 96.3 & 100 \\
\hline & $\overline{\mathrm{X}}$ & $1.714^{b}$ & $7.623^{a}$ & - \\
\hline \multirow{3}{*}{ Chrysomya putoria } & $\mathrm{n}$ & 13 & 191 & 204 \\
\hline & $\%$ & 6.4 & 93.6 & 100 \\
\hline & $\overline{\mathrm{X}}$ & $1.035^{b}$ & $2.690^{a}$ & - \\
\hline \multirow{3}{*}{ Hemilucilia segmentaria } & $\mathrm{n}$ & 56 & 94 & 150 \\
\hline & $\%$ & 37.3 & 62.7 & 100 \\
\hline & $\bar{X}$ & $1.559^{b}$ & $2.150^{a}$ & - \\
\hline \multirow{3}{*}{ Lucilia eximia } & $\mathrm{n}$ & 191 & 223 & 414 \\
\hline & $\%$ & 46.1 & 53.9 & 100 \\
\hline & $\overline{\mathrm{X}}$ & $2.292^{a}$ & $3.054^{a}$ & - \\
\hline \multirow{3}{*}{ Ophyra aenescens } & $\mathrm{n}$ & 264 & 1,962 & 2,226 \\
\hline & $\%$ & 11.9 & 88.1 & 100 \\
\hline & $\overline{\mathrm{X}}$ & $3.332^{b}$ & $8.018^{a}$ & - \\
\hline \multirow{3}{*}{ Ophyra chalcogaster } & $\mathrm{n}$ & 97 & 66 & 163 \\
\hline & $\%$ & 59.5 & 40.5 & 100 \\
\hline & $\overline{\mathrm{X}}$ & $2.239^{a}$ & $1.815^{a}$ & - \\
\hline \multirow{3}{*}{ Synthesiomyia nudiseta } & $\mathrm{n}$ & 743 & 282 & 1,025 \\
\hline & $\%$ & 72.5 & 27.5 & 100 \\
\hline & $\overline{\mathrm{X}}$ & $4.960^{a}$ & $3.808^{a}$ & - \\
\hline \multirow{3}{*}{ Fannia pusio } & $\mathrm{n}$ & 2,534 & 580 & 3,114 \\
\hline & $\%$ & 81.4 & 18.6 & 100 \\
\hline & $\overline{\mathrm{X}}$ & $10.360^{a}$ & $5.404^{b}$ & - \\
\hline \multirow{3}{*}{ Peckia intermutans } & $\mathrm{n}$ & 13 & 4 & 17 \\
\hline & $\%$ & 76.5 & 23.5 & 100 \\
\hline & $\overline{\mathrm{X}}$ & $1.071^{a}$ & $0.845^{a}$ & - \\
\hline
\end{tabular}

$a, b$ : averages for each species are not significantly different at $5 \%(\mathrm{p}<0.05)$. The averages were compared using the Tukey test; $\mathrm{n}$ : absolute abundance of species; \%: relative abundance of species; $\overline{\mathrm{X}}$ : average values.

carried out in temperate countries, where the necrophagous insects clearly obeyed an arrival order (succession) on the models (Bornemissza 1957, Rodriguez \& Bass 1983). However, the seasonal variation significantly influenced the abundance of some studied species. In summer, with higher average temperatures, there was a large increase in the species abundance, as observed by Tullis and Goff (1987), Tomberlin and Adler (1998) and Oliveira-Costa et al. (2001a).

Family Calliphoridae - The Calliphoridae, including species whose larvae are voracious and competitive, were the most important group in the decomposition process (Smith 1986, Greenberg 1991). Many of the species are indicators of PMI or can be used for the detection of drug/chemical residuals (Zuben et al. 1996, Carvalho et al. 2001, Introna et al. 2001).

C. megacephala was the most abundant Calliphoridae in the whole experiment, with $96.3 \%$ of the individuals collected in the summer. Larvae were also found. This result corroborates the findings of Early and Goff (1986) and Tullis and Goff (1987), who found the same pattern in cat and pig carcasses in Hawaii. In Brazil, Oliveira-Costa et al. (2001b) found this species of blowfly colonising human corpses in Rio de Janeiro. Andrade et al. (2005) also collected maggots of this species in the decay stage in human corpses. However, according to Souza and Linhares (1997), this species could not be fundamentally necrophagous because collected few individuals on pig carcasses in Campinas, state of São Paulo (SP). 


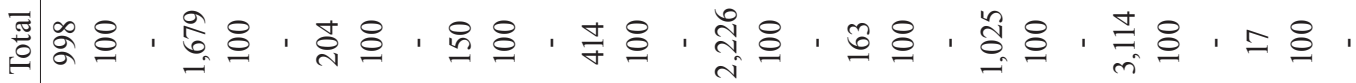

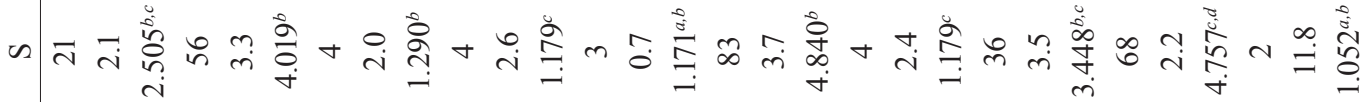
ลे

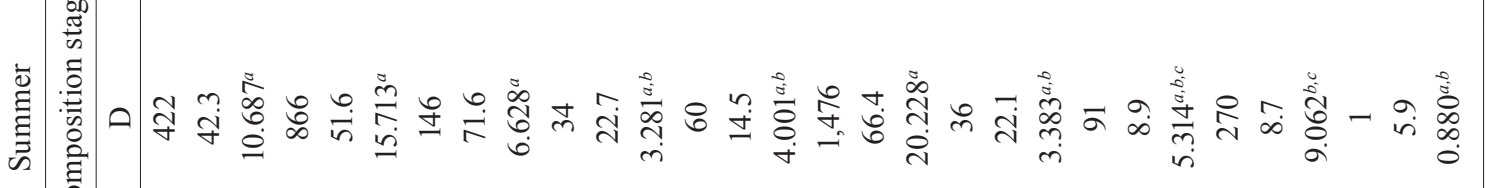

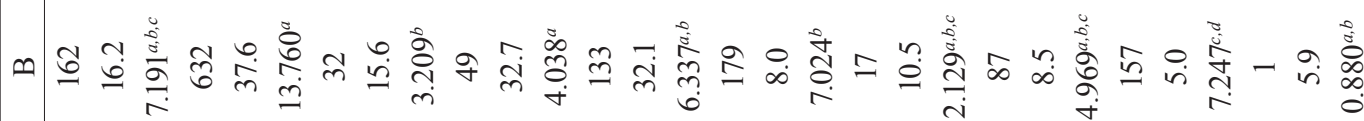

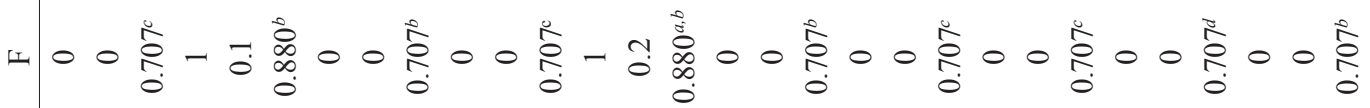

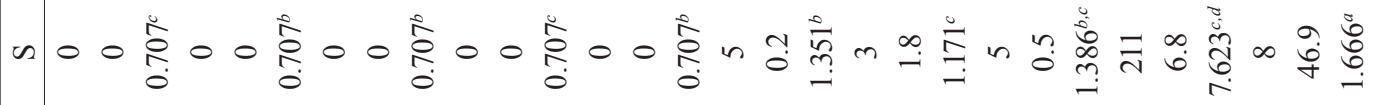

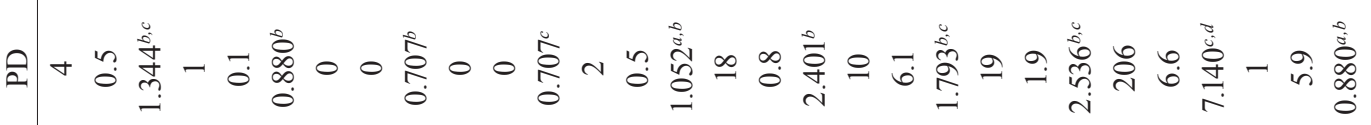

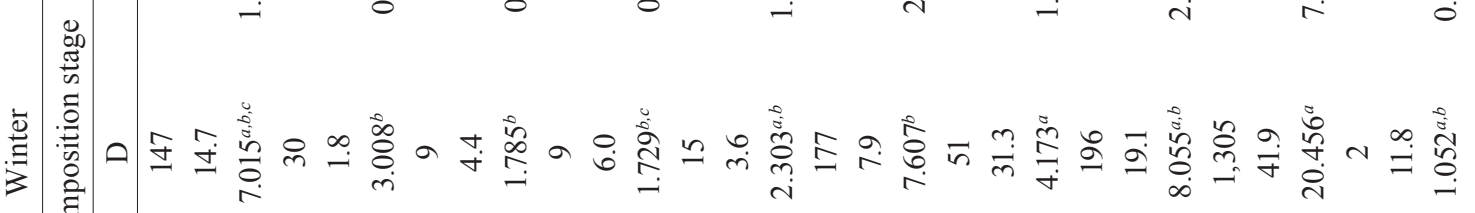

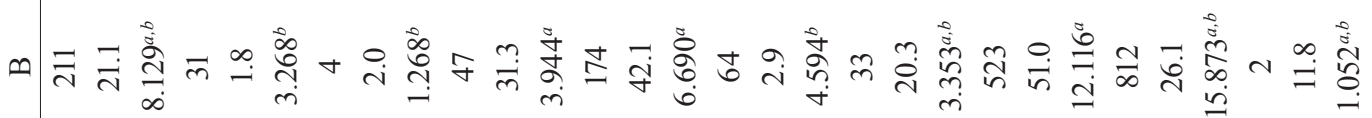

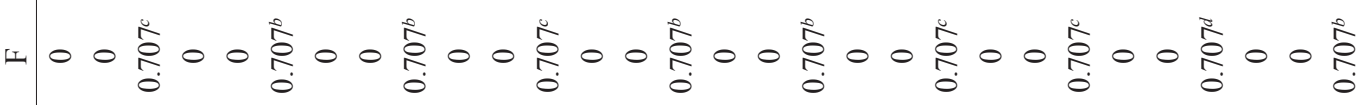
$\Rightarrow \partial^{0}\left|x=\partial^{0}\right| x=\partial^{0}\left|x=\partial^{0}\right| x=\partial^{0}\left|x=\partial^{0}\right| x=d^{0}\left|x=\partial^{0}\right| x=\partial^{0}\left|x=\partial^{0}\right| x \mid$ 
The second most abundant Calliphoridae species was $C$. albiceps, with 998 specimens; this species appeared mainly in the summer $(63.7 \%)$ and a large number of immature specimens were collected in both seasons. This fact is not surprising, because C. albiceps is one of the most synatropic flies in Brazil (d'Almeida \& Lopes 1983). The immature stages of C. albiceps have a predatory behaviour mainly when food resources are scarce (Faria \& Godoy 2001). According to OliveiraCosta (2007), C. albiceps is considered to be a forensic indicator species in Southeast Brazil, indicating that this species arrives on the carcass immediately after its exposure. Accordingly, many authors reported its occurrence and importance in the degradation of human corpses in Brazil and throughout the world (Monteiro-Filho \& Penereiro 1987, Salviano 1996, Carvalho et al. 2000, Marchiori et al. 2000, Arnaldos et al. 2001, Oliveira-Costa et al. 2001b, Wolff et al. 2001, Grassberger et al. 2003).

L. eximia was the third most collected Calliphoridae species. It was most abundant in the first days of decomposition stages (fresh and bloating), in accordance with other works involving entomological succession in carcasses (Salviano 1996, Carvalho et al. 2000).

In relation to $C$. putoria, few specimens were collected compared to C. albiceps, although immature specimens were collected in the carcass in winter and summer. Other authors have also found immature stages of this species in carcass models and human corpses (Salviano 1996, Carvalho et al. 2000, Oliveira-Costa 2001b). However, Souza and Linhares (1997) suggested that this species visits the carcass only to feed because its ovarian follicles appear in the process of vitellogenesis.

$H$. segmentaria was less abundant when compared to the other species; however, it was a pioneer as much in winter as in summer, appearing and ovipositing immediately after the exposition of the carcasses. A similar result was reported by Salviano (1996), who pointed out that this species was one of the most important ones in the decomposition process for the municipality of Rio de Janeiro. Souza and Linhares (1997) also captured few specimens of $H$. segmentaria in pig carcasses in Campinas-SP and they also noted the presence of immature specimens in all studied seasons.

Family Muscidae - The most abundant species among the Muscidae was $O$. aenescens, with a total of 2,226 specimens (42\%) collected. A large number of immature specimens were collected on the carcasses in the decay stage thereby suggesting that $O$. aenescens was the most important species in this family. This result corroborates that of Salviano (1996), who reported that O. aenescens was the second most abundant Muscidae species and also found a large number of immature specimens in the bloated and decay stages.

$O$. aenescens were significantly abundant during the decay stage in summer and a large number of larvae were observed and collected on the carcasses in this stage. Early and Goff (1986) and Tullis and Goff (1987) also noted that this species had a preference for more advanced stages of decomposition (decay and post-decay). In Brazil, Salviano (1996) observed the same occurrence pattern for this species.
S. nudiseta was the third most abundant Muscidae species $(20 \%)$ and $72 \%$ were collected in winter; a similar result for this season was found by Salviano (1996). Immature specimens of $S$. nudiseta were found colonising the carcasses in the two studied seasons and, according to many authors, this species is frequently associated with the decomposition of carcasses and human corpses (Jirón et al. 1983, Lord et al. 1992, Omar \& Marwi 1994). Besides the apparent preference for winter, S. nudiseta also had a significant abundance in the bloated stage during this season. Different results were observed by Tullis and Goff (1987), who found adults and immature specimens only in the decay and post-decay stages.

Our study was the first time that $O$. chalcogaster was collected colonising pig carcasses in Rio de Janeiro state. Only immature forms of $O$. aenescens have been collected in experiments involving the decomposition of carcasses and human corpses (Salviano 1996, OliveiraCosta 2007). Conversely, in Campinas-SP, Carvalho et al. (2000) collected immature specimens as much in human corpses as in pig carcasses and thus considered this species to be a PMI indicator.

Family Fanniidae - F. pusio was the most abundant species of this family, but the colonisation occurred only in the winter season. These results disagree with Salviano (1996), who stated that this species was more abundant in spring in the municipality of Rio de Janeiro. In the Rio de Janeiro Zoo, d'Almeida (1989) reported the Fanniidae as the most abundant of calyptrate dipterans collected on a variety of animal and vegetable substrates. In Campinas, SP, Souza and Linhares (1997) indicated the preference of the species for the fall season. In the same study, the author reported that $F$. pusio has little forensic potential because immature forms were not found in any of his experiments with pig carcasses in that state. Smith (1986) affirmed that the species of the genus Fannia had preference for the warmer seasons and were found colonising carcasses and human corpses.

In this study, $F$. pusio was more abundant in the decay stage in winter, in agreement with Tullis and Goff (1987). On the other hand, Salviano (1996) observed that this species has a preference for the final stages of decomposition (post-decay and skeletonisation).

Family Sarcophagidae - Despite the higher diversity observed in this family, only P. intermutans was observed colonising the carcass during the experiment in both studied seasons. This species was also found by both Salviano (1996) and Souza and Linhares (1997) in domestic pig carcasses and by Carvalho et al. (2000) in human corpses. Although this species was found colonising the carcasses, it appeared in relatively small numbers in comparison to the other species during this experiment.

Our results show that the seasons can influence the composition of necrophagous dipterans. The summer seems to be the season where the majority of species were more active, except for F. pusio. The study also suggests that the spatial distribution of species can be influenced by physiographic differences. This observation is supported by the higher attraction exerted on the species by area 2 and also by the differences in the chrono- 
logy of decomposition stages that occurred in this area. Another important point on the attraction of the species is the influence of decomposition stages. The bloated stage and the decay stage were the most attractive to the dipterous colonisers in this study.

\section{REFERENCES}

Andrade HTA, Varela-Freire AA, Batista MJA, Medeiros JF 2005. Calliphoridae (Diptera) coletados em cadáveres humanos no Rio Grande do Norte. Neotrop Entomol 34: 855-856.

Arnaldos I, Romera E, García MD, Luna A 2001. An initial study on the succession of sarcosaprophagous Diptera (Insecta) on carrion in the Southeastern Iberian Peninsula. Int J Legal Med 114: $156-162$.

Barbosa RR, Mello-Patiu CA, Mello RP, Queiroz MMC 2009. New records of calyptrate dipterans (Fanniidae, Muscidae and Sarcophagidae) associated with the decomposition of domestic pigs in Brazil. Mem Inst Oswaldo Cruz 104: 923-926.

Benecke M 2001. A brief history of forensic entomology. Forensic Sci Int 120: 2-14.

Benecke M, Lessig R 2001. Child neglect and forensic entomology. Forensic Sci Int 120: 155-159.

Bornemissza GF 1957. An analysis of arthropod succession in carrion and the effect of its decomposition on the soil fauna. Aus J Zool: 5 1-12.

Byrd JH, Castner JL 2001. Forensic entomology: the utility of arthropods in legal investigations, CRC Press, Boca Raton, 488 pp.

Carvalho CJB, Couri MS 2002. Basal groups. In CJB Carvalho (ed.), Muscidae (Diptera) of the Neotropical Region: taxonomy, Part I, Editora Universidade Federal do Paraná, Curitiba, p. 17-259.

Carvalho CJB, Mello-Patiu CA 2008. Key to the adults of the most common forensic species of Diptera in South America. Rev Bras Entomol 52: 390-406.

Carvalho CJB, Moura MO, Ribeiro PB 2002. Chave para adultos de dípteros (Muscidae: Fanniidae: Anthomyiidae) associados ao ambiente humano no Brasil. Rev Bras Entomol 46: 107-114.

Carvalho LML, Linhares AX, Trigo JR 2001. Determination of drug levels and the effect of diazepam on the growth of necrophagous flies of forensic importance in Southeastern Brazil. Forensic Sci Int 120: 140-144.

Carvalho LML, Thyssen PJ, Linhares AX, Palhares FAB 2000. A checklist of arthropods associated with pig carrion and human corpses in Southeastern Brazil. Mem Inst Oswaldo Cruz 95: 135138 .

Catts EP, Haskell NH 1991. Entomology and death: a procedural guide, Joyce's Print Shop, Clemson, 182 pp.

Couri MS, Carvalho CJB 2002. Apical groups. In CJB Carvalho (ed.), Muscidae (Diptera) of the Neotropical Region: taxonomy, Part II, Editora Universidade Federal do Paraná, Curitiba, p. 133-287.

d'Almeida JM 1989. Substratos utilizados para a criação de dípteros caliptrados no Jardim Zoológico do Rio de Janeiro (Rio-Zoo). Mem Inst Oswaldo Cruz 84: 257-264.

d'Almeida JM, Lopes HS 1983. Sinantropia em dípteros caliptrados (Calliphoridae) no Estado do Rio de Janeiro. Arq Univ Fed Rur Rio de Janeiro 6: 38-48.

Early M, Goff ML 1986. Arthropod succession patterns in exposed carrion on the island of O'ahu, Hawaiian Islands, USA. J Med Entomol 23: 520-531.

Erzinçlioglu Z 1985. Few flies on forensic entomologists. New Sci: $15-17$.
Faria LDB, Godoy WAC 2001. Prey choice by facultative predator larvae of Chrysomya albiceps (Diptera: Calliphoridae). Mem Inst Oswaldo Cruz 96: 875-878.

Goff ML 2000. A fly for the prosecution, Harvard University Press, Cambridge, $225 \mathrm{pp}$.

Grassberger M, Friederich E, Reiter C 2003. The blowfly Chrysomya albiceps (Wiedemann) (Diptera: Calliphoridae) as a new forensic indicator in central Europe. Int J Legal Med 117: 75-81.

Greenberg B 1991. Flies as forensic indicators. J Med Entomol 28: $565-577$.

Introna FJ, Campobasso CP, Goff ML 2001. Entomotoxicology. Forensic Sci Int 120: 42-47.

Jirón LF, Vargas LG, Alvarado E 1983. Four muscoid (Sarcophagidae and Muscidae) associated with human cadavers in Costa Rica. Brenesia 21: 3-5.

Johnson MD 1975. Seasonal and microseral variations in the insect populations on carrion. Am Midl Nat 93: 79-90.

Kamal AS 1958. Comparative study of thirteen species of sarcosaprophagous Calliphoridae and Sarcophagidae (Diptera). Ann Ent Soc Am 51: 261-271.

Lord WD, Adkins TR, Catts EP 1992. The use of Synthesiomyia nudiseta (Diptera: Muscidae) and Calliphora vicina (Diptera: Calliphoridae) to estimate the time of death of a body buried under a house. J Agric Entomol 94: 227-235.

Marchiori CH, Silva CG, Caldas CIS, Almeida KGS, Teixeira FF, Linhares AX 2000. Dípteros muscóides associados com carcaça de suíno e seus parasitóides em área de pastagem e de mata em Goiás. Arq Bras Med Vet Zootec 67: 167-170.

McAlpine JF 1989. Phylogeny and classification of Muscomorpha. In JF McAlpine, DM Wood (eds), Manual of Neartic Diptera. Reserch Branch Agriculture Canada, Ottawa, p. 1333-1581.

Mello RP 2003. Chave para determinação de formas adultas das espécies da família Calliphoridae (Diptera: Brachycera: Cyclorrhapha) encontradas no Brasil. Entomol Vec 10: 255-268.

Monteiro-Filho ELA, Penereiro JL 1987. Estudo da decomposição e sucessão sobre uma carcaça animal numa área do estado de São Paulo, Brasil. Rev Bras Biol 47: 289-295.

Oliveira-Costa J 2007. Entomologia forense - quando os insetos são vestigios, 2nd ed., Millennium, Campinas, $420 \mathrm{pp}$.

Oliveira-Costa J, Mello-Patiu CA, Lopes SM 2001a. Influência de diferentes fatores na freqüência de dípteros muscóides em cadáveres humanos no Rio de Janeiro. Bol Mus Nac Zoo 470: 1-10.

Oliveira-Costa J, Mello-Patiu CA, Lopes SM 2001b. Dípteros muscóides associados com cadáveres humanos na cena da morte no estado do Rio de Janeiro - Brasil. Bol Mus Nac Zoo 464: 1-6.

Omar B, Marwi MA 1994. Maggots of Synthesiomyia nudiseta (Wulp) (Diptera: Muscidae) as decomposers of corpse found in doors in Malaysia. Trop Biomed 11: 145-148.

Pujol-Luz JR, Arantes LC, Constantino R 2008. Cem anos da entomologia forense no Brasil (1908-2008). Rev Bras Entomol 52: 485-492.

Rodriguez WC, Bass WM 1983. Insect activity and its relationship to decay rates of human cadavers in East Tennessee. J Forensic Sci 28: $423-432$

Salviano RJB 1996. Sucessão de Diptera Calyptratae em carcaça de Sus scrofa, $L$. MsD Thesis, Universidade Federal Rural do Rio de Janeiro, Rio de Janeiro, 123 pp.

Smith KGV 1986. A manual of forensic entomology, Cornell University Press, Ithaca, $205 \mathrm{pp}$ 
Sokal RR, Rohlf FJ 1995. Biometry: the principles and practice of statistics in biological research, 3rd ed. WH Freeman and Co, New York, 887 pp.

Souza AM, Linhares AX 1997. Diptera and Coleoptera of potential forensic importance in Southeastern Brazil: relative abundance and seasonality. Med Vet Entomol 11: 8-12.

Tomberlin JK, Adler PH 1998. Seasonal colonization and decomposition of rat carrion in water and on land in open field in South Carolina. J Med Entomol 35: 704-709.

Tullis K, Goff ML 1987. Arthropod succession in exposed carrion in a tropical rainforest on O'ahusland, Hawaii's. J Med Entomol 24: $332-339$.

Wolff M, Uribe A, Ortiz A, Duque PA 2001. A preliminary study of forensic entomology in Medellín, Colombia. Forensic Sci Int 120: $53-59$.

Yates DK, Wiegmann BM 1999. Congruence and controversy: toward a higher-level phylogeny of Diptera. Annu Rev Entomol 44: 397-428.

Zuben CJ, Bassanezi FR, Zuben FJ 1996. Theoretical approaches to forensic entomology: I. Mathematical model of post feeding larval dispersal. J Appl Entomol 120: 379-382. 


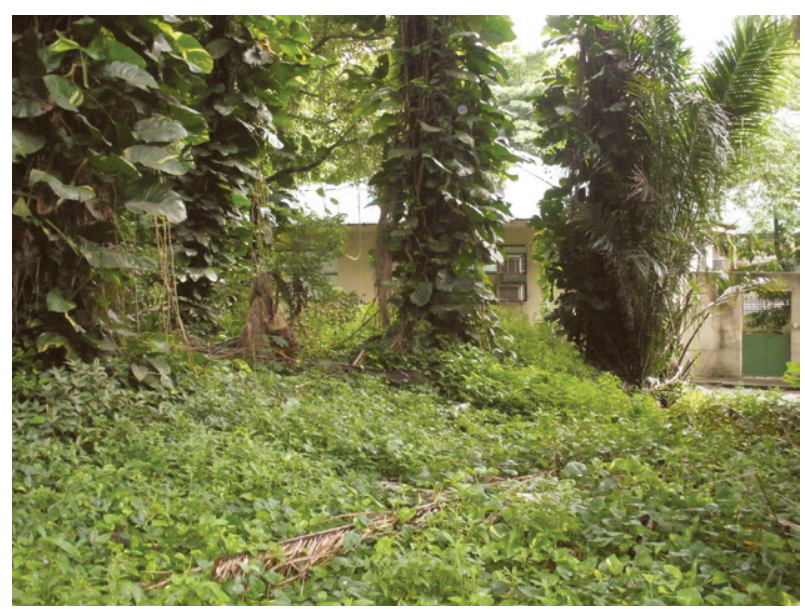

Fig. 1: view of area 1.

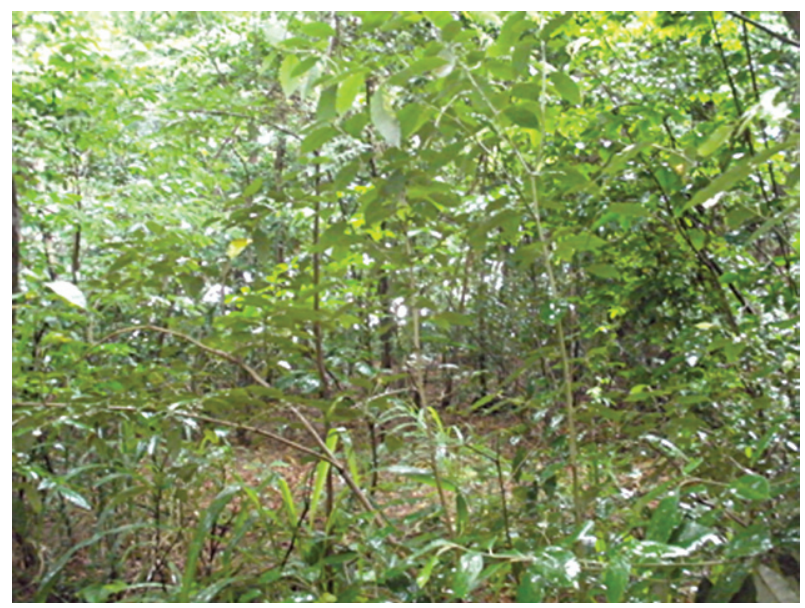

Fig. 2: view of area 2.

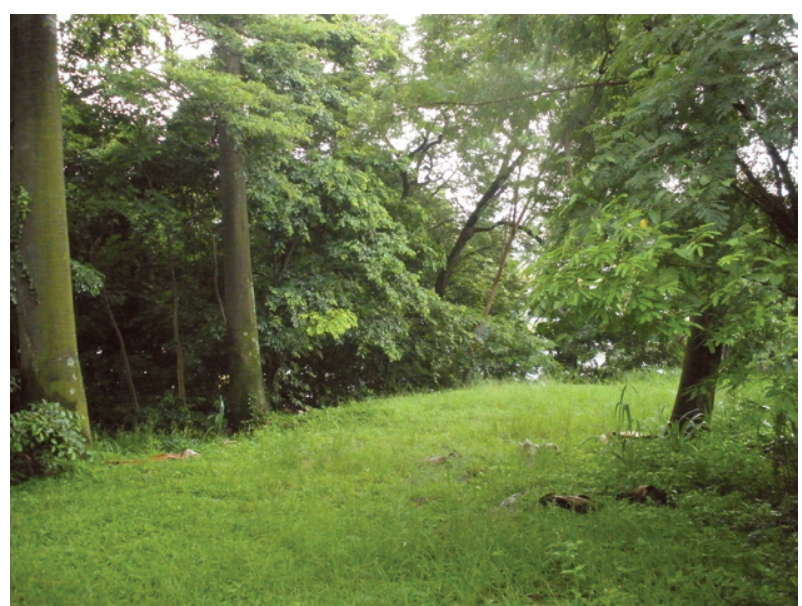

Fig. 3: view of area 3. 
TABLE I

Absolute and relative abundance of colonizing species in each area during the summer of 2008

\begin{tabular}{|c|c|c|c|c|c|}
\hline \multirow[b]{2}{*}{ Species } & & \multicolumn{3}{|c|}{ Area } & \multirow[b]{2}{*}{ Total } \\
\hline & & 1 & 2 & 3 & \\
\hline \multirow{3}{*}{ Chrysomya albiceps } & $\mathrm{n}$ & 294 & 306 & 36 & 636 \\
\hline & $\%$ & 46.2 & 48.1 & 5.7 & 100 \\
\hline & $\bar{X}$ & $5.286^{a, b}$ & $6.526^{a}$ & $2.248^{b}$ & - \\
\hline \multirow{3}{*}{ Chrysomya megacephala } & $\mathrm{n}$ & 586 & 899 & 132 & 1,617 \\
\hline & $\%$ & 36.2 & 55.6 & 8.2 & 100 \\
\hline & $\bar{X}$ & $7.664^{a, b}$ & $10.894^{a}$ & $4.306^{b}$ & - \\
\hline \multirow{3}{*}{ Chrysomya putoria } & $\mathrm{n}$ & 54 & 115 & 22 & 191 \\
\hline & $\%$ & 28.3 & 60.2 & 11.5 & 100 \\
\hline & $\bar{X}$ & $2.328^{a}$ & $3.798^{a}$ & $1.946^{a}$ & - \\
\hline \multirow{3}{*}{ Hemilucilia segmentaria } & $\mathrm{n}$ & 23 & 54 & 17 & 94 \\
\hline & $\%$ & 24.5 & 57.5 & 18.0 & 100 \\
\hline & $\overline{\mathrm{X}}$ & $1.772^{b}$ & $2.954^{a}$ & $1.726^{b}$ & - \\
\hline \multirow{3}{*}{ Lucilia eximia } & $\mathrm{n}$ & 150 & 47 & 26 & 223 \\
\hline & $\%$ & 67.2 & 21.1 & 11.7 & 100 \\
\hline & $\bar{X}$ & $4.450^{a}$ & $2.598^{a}$ & $2.114^{a}$ & - \\
\hline \multirow{3}{*}{ Ophyra aenescens } & $\mathrm{n}$ & 439 & 1,389 & 134 & 1,962 \\
\hline & $\%$ & 22.4 & 70.8 & 6.8 & 100 \\
\hline & $\bar{X}$ & $6.944^{a, b}$ & $12.944^{a}$ & $4.168^{b}$ & - \\
\hline \multirow{3}{*}{ Ophyra chalcogaster } & $\mathrm{n}$ & 11 & 4 & 9 & 66 \\
\hline & $\%$ & 16.7 & 69.7 & 13.6 & 100 \\
\hline & $\bar{X}$ & $1.246^{b}$ & $1.398^{b}$ & $2.804^{a}$ & - \\
\hline \multirow{3}{*}{ Synthesiomyia nudiseta } & $\mathrm{n}$ & 141 & 114 & 27 & 282 \\
\hline & $\%$ & 50 & 40.4 & 9.6 & 100 \\
\hline & $\bar{X}$ & $4.766^{a}$ & $4.380^{a}$ & $2.282^{a}$ & - \\
\hline \multirow{3}{*}{ Fannia pusio } & $\mathrm{n}$ & 295 & 168 & 117 & 580 \\
\hline & $\%$ & 50.9 & 28.9 & 20.2 & 100 \\
\hline & $\bar{X}$ & $6.632^{a}$ & $5.206^{a}$ & $4.378^{a}$ & - \\
\hline \multirow{3}{*}{ Peckia intermutans } & $\mathrm{n}$ & 2 & 2 & 0 & 4 \\
\hline & $\%$ & 50 & 50 & 0 & 100 \\
\hline & $\bar{X}$ & $0.914^{a}$ & $0.914^{a}$ & $0.710^{a}$ & - \\
\hline
\end{tabular}

$a, b$ : averages for each species are not significantly different at $5 \%(\mathrm{p}<0.05)$. The averages were compared using the Tukey test; $\mathrm{n}$ : absolute abundance of species; \%: relative abundance of species; $\overline{\mathrm{X}}$ : average values. 
TABLE II

Absolute and relative abundance of colonizing species in each area during the winter of 2007

\begin{tabular}{|c|c|c|c|c|c|}
\hline \multirow[b]{2}{*}{ Species } & & \multicolumn{3}{|c|}{ Area } & \multirow[b]{2}{*}{ Total } \\
\hline & & 1 & 2 & 3 & \\
\hline & $\mathrm{n}$ & 87 & 98 & 177 & 362 \\
\hline \multirow[t]{3}{*}{ Chrysomya albiceps } & $\%$ & 24.0 & 27.1 & 48.9 & 100 \\
\hline & $\overline{\mathrm{X}}$ & $3.220^{a}$ & $3.316^{a}$ & $4.204^{a}$ & - \\
\hline & $\mathrm{n}$ & 9 & 34 & 19 & 62 \\
\hline \multirow[t]{3}{*}{ Chrysomya megacephala } & $\%$ & 14.6 & 54.8 & 30.6 & 100 \\
\hline & $\bar{X}$ & $1.290^{a}$ & $2.168^{a}$ & $1.688^{a}$ & - \\
\hline & $\mathrm{n}$ & 2 & 7 & 4 & 13 \\
\hline \multirow[t]{3}{*}{ Chrysomya putoria } & $\%$ & 15.4 & 53.9 & 30.7 & 100 \\
\hline & $\overline{\mathrm{X}}$ & $0.884^{a}$ & $1.180^{a}$ & $1.044^{a}$ & - \\
\hline & $\mathrm{n}$ & 12 & 18 & 26 & 56 \\
\hline \multirow[t]{3}{*}{ Hemilucilia segmentaria } & $\%$ & 21.5 & 32.1 & 46.4 & 100 \\
\hline & $\overline{\mathrm{X}}$ & $1.348^{a}$ & $1.652^{a}$ & $1.680^{a}$ & - \\
\hline & $\mathrm{n}$ & 7 & 54 & 130 & 191 \\
\hline \multirow[t]{3}{*}{ Lucilia eximia } & $\%$ & 3.7 & 28.3 & 68.0 & 100 \\
\hline & $\overline{\mathrm{X}}$ & $1.224^{a}$ & $2.462^{a}$ & $3.192^{a}$ & - \\
\hline & $\mathrm{n}$ & 101 & 102 & 61 & 264 \\
\hline \multirow[t]{3}{*}{ Ophyra aenescens } & $\%$ & 38.3 & 38.6 & 23.1 & 100 \\
\hline & $\overline{\mathrm{X}}$ & $3.576^{a}$ & $3.688^{a}$ & $2.732^{a}$ & - \\
\hline & $\mathrm{n}$ & 37 & 35 & 25 & 97 \\
\hline \multirow[t]{3}{*}{ Ophyra chalcogaster } & $\%$ & 38.1 & 36.1 & 25.8 & 100 \\
\hline & $\bar{X}$ & $2.490^{a}$ & $2.384^{a}$ & $1.846^{a}$ & - \\
\hline & $\mathrm{n}$ & 72 & 336 & 335 & 743 \\
\hline \multirow[t]{3}{*}{ Synthesiomyia nudiseta } & $\%$ & 9.7 & 45.2 & 45.1 & 100 \\
\hline & $\overline{\mathrm{X}}$ & $3.168^{a}$ & $5.824^{a}$ & $5.892^{a}$ & - \\
\hline & $\mathrm{n}$ & 688 & 1,441 & 405 & 2,534 \\
\hline \multirow[t]{3}{*}{ Fannia pusio } & $\%$ & 27.1 & 56.9 & 16.0 & 100 \\
\hline & $\overline{\mathrm{X}}$ & $9.736^{a, b}$ & $14.532^{a}$ & $6.814^{b}$ & - \\
\hline & $\mathrm{n}$ & 4 & 7 & 2 & 13 \\
\hline \multirow[t]{2}{*}{ Peckia intermutans } & $\%$ & 30.8 & 53.9 & 15.3 & 100 \\
\hline & $\overline{\mathrm{X}}$ & $1.118^{a}$ & $1.118^{a}$ & $0.914^{a}$ & - \\
\hline
\end{tabular}

$a, b$ : averages for each species are not significantly different at $5 \%(\mathrm{p}<0.05)$. The averages were compared using the Tukey test; $n$ : absolute abundance of species; \%: relative abundance of species; $\overline{\mathrm{X}}$ : average values. 